\title{
Activity in MCF-7 Estrogen-sensitive Breast Cancer Cells of Capsicodendrin from Cinnamosma fragrans
}

\author{
ULYANA MUNOZ ACUNA ${ }^{\#}$, NATHAN EZZONE, \\ L. HARINANTENAINA RAKOTONDRAIBE and ESPERANZA J. CARCACHE DE BLANCO \\ Division of Medicinal Chemistry and Pharmacognosy, College of Pharmacy, \\ The Ohio State University, Columbus, OH, U.S.A.
}

\begin{abstract}
Background/Aim: Effect of capsicodendrin on the $N F-k B$ pathway was studied in MCF-7 cancer cells. Materials and Methods: The transcription factor assay was used to screen for $N F-k B$ activity. The effect on IKK $\beta, I C A M-1$, and caspase-7 were studied using western blot. Caspase-1 was studied using Promega Caspase-Glo ${ }^{\circledR}$ assay. Reactive oxygen species (ROS) were detected using the fluorescent probe DCFH-DA. The potentiometric dye JC-1 was used to assess mitochondrial membrane potential $(\Delta \Psi \mathrm{m})$ and the cell cycle was examined using a fluorescence-activated cell sorter. Results: $N F-\kappa B$ p65 inhibitory effect was $I C_{50}=8.6 \mu M$ and cytotoxic activity was $I C_{50}=7.5 \mu M$. The upstream IKK and the downstream ICAM-1 were down-regulated. Sub $G_{1}$-phase population increased to $81 \%$ after $12 \mathrm{~h}$ of treatment with capsicodendrin $(10 \mu M)$ and there was no loss of $\triangle \Psi M$. Conclusion: Increased levels of intracellular ROS promoted activity of caspase-1 and induced cell death in MCF-7 cells. Capsicodendrin may be a future anticancer agent that prevents the progression of metastatic breast cancer.
\end{abstract}

Despite new effective anticancer treatments, chemoresistant breast tumor cells spread to other organs and the survival rate $(26 \%)$ remains low for metastatic breast cancer (1-3). Breast cancer patients have high serum levels of proinflammatory cytokine tumor necrosis factor- $\alpha($ TNF- $\alpha)$. It

This article is freely accessible online.

\#Current address: Department of Chemistry and Biomedical Sciences, Faculty of Health and Life Sciences, Linnaeus University, Kalmar, Sweden.

Correspondence to: Esperanza J. Carcache de Blanco, Division of Medicinal Chemistry and Pharmacognosy, College of Pharmacy, $500 \mathrm{~W} \mathrm{12}$ th Avenue, Columbus, OH 43210-1291, U.S.A. Tel: +1 6142921335, e-mail: carcachedeblanco.1@osu.edu

Key Words: Capsicodendrin, MCF-7, NF-kB, IKK $\beta$, ICAM-1, ROS, caspase-7, caspase-1. has also been shown that transmembrane TNF- $\alpha$ plays a role in the development of chemoresistance and metastasis of breast cancer cells (4-5). TNF- $\alpha$ induces the activity on the nuclear factor kappa B (NF-kB) (Figure 1), which is a heterodimer composed of p65 bound to IkB. IkB kinase (IKK) phosphorylates IkB. The release from IkB activates $\mathrm{NF}-\mathrm{kB}$ before it is translocated to the nucleus, and the blockage of both IKK $\beta$ and nuclear import reduces tumor expansion (6-8). Activation of the NF-kB p65 signal plays an important role in vivo in tumor progression and promotes the resistance to certain tumorigenic agents and chemotherapy $(7,8)$. Previous studies have shown that NFkB p65 prevents cancer cells from entering apoptosis and contributes to chemoresistance as well as to the progression of the disease (9). In addition, it has been shown that MCF7 estrogen-sensitive breast cancer cells overexpress the antiapoptotic protein Bcl-2, which prevents apoptosis. Thus, inhibition of NF-kB p65 prevents tumor growth and metastasis of estrogen-sensitive breast cancer $(10,11)$.

Moreover, intracellular adhesion molecule ICAM-1 has been shown to be induced by TNF- $\alpha$ in MCF-7 cells (Figure 1). Herein, the effects on ICAM-1 and the anti-proliferative effect of capsicodendrin in MCF-7 estrogen-dependent breast cancer cells were investigated. Also, the effect of capsicodendrin on the NF-kB pathway and the viability of treated cells was further analyzed. The apoptotic effect and the effect on cellular oxidative stress was also investigated in vitro. The aim of this study was to assess the possible mechanism of action through which capsicodendrin (Figure 1A) induces cell-cycle arrest in breast cancer cells.

\section{Materials and Methods}

Cell culture. The MCF-7 cancer cell line was obtained from American Type Culture Collection (ATCC\# HTB-22, Manassas, VA, USA). Cells were cultured in Dulbecco's modified Eagle's medium (DMEM) and Roswell Park Memorial Institute medium (RPMI1640), containing $10 \%$ fetal bovine calf serum and $10 \%$ AntibioticAntimycotic (Gibco, Rockville, MD, USA). Cells were kept at $37^{\circ} \mathrm{C}$ and in an atmosphere containing $5 \% \mathrm{CO}_{2}$. 
SRB assay. MCF-7 cells were plated in a 96-well plate and treated with capsicodendrin for $72 \mathrm{~h}$ at $37^{\circ} \mathrm{C}$ and incubated in a $5 \% \mathrm{CO}_{2}$ atmosphere. Cells were fixed using $20 \%$ trichloroacetic acid for $30 \mathrm{~min}$, followed by staining with sulforhodamine (SRB) $(0.4 \%)$ for $30 \mathrm{~min}$ at room temperature. SRB was removed by washing with acetic acid three times. After adding $200 \mu \mathrm{M}$ Tris base solution to each well, the 96-well plates were placed on a shaker for $5 \mathrm{~min}$. Absorbance reading was performed at a wavelength of $515 \mathrm{~nm}$ using a Fluostar Optima plate reader (BMG Labtech Inc, Durham, NC, USA). Paclitaxel (Tocris Bioscience, Bristol, UK) was used as a positive control.

$N F-\kappa B$ assay. The NF-kB p65 assay was performed according to a previously established protocol (12). Nuclear extracts were prepared from HeLa cells and the Transcription Assay System (Pierce Biotechnology, Rockford, IL, USA) was used to evaluate the binding affinity of the NF- $\mathrm{kB}$ subunit $\mathrm{p} 65$ to the biotinylated consensus sequence. Luminescence was detected using a Fluostar Optima plate reader (BMG Labtech Inc). Rocaglamide (Enzo Life Sciences, Inc., Farmingdale, NY, USA) was used as a positive control.

Immunoblotting. Cells were treated with capsicodendrin at different concentrations $(0.008,0.016,0.4,2.0$ and $10 \mu \mathrm{M})$ for $3 \mathrm{~h}$. Briefly, cells were lysed using PhosphoSafe Lysis Buffer (Novagen, Madison, WI, USA). Protein concentration was determined by using a Bradford protein assay kit and albumin standard (Thermo Scientific, Waltham, MA, USA). Absorbance was measured using a Fluostar Optima plate reader (BMG Labtech Inc.). Lysates were analyzed by western blot analysis with primary $(1: 1,000)$ and secondary antibodies $(1: 2,000)$. Equal amounts of protein $(20 \mu \mathrm{g})$ were loaded together with a LDS sample loading buffer (Invitrogen, Carlsbad, CA, USA) and resolved using Nu-PAGE 10\% SDS-PAGE Bis-Tris gels together with SeeBlue ${ }^{\circledR}$ Plus2 Pre-Stained Standard (Invitrogen). Proteins were transferred to a polyvinylidene fluoride (PVDF) membrane using transfer buffer, tris-buffered saline solution with Tween $20^{\circledR}$ (TBS-T). The blots were then blocked at room temperature using non-fat milk and probed using primary antibodies against each target protein including NF-kB p65, IKK $\beta$, ICAM-1, and caspase-7, using BSA in TBS-T overnight. Conjugated antibodies were detected using chemiluminescent substrates with a Supersignal Femto kit from Thermo Scientific.

Reactive oxygen species. A reactive oxygen species (ROS) assay was performed following a previously described procedure (13). Generated intracellular levels of ROS were measured using the fluorescent probe 2',7'-dichlorodihydrofluorescein diacetate (DCFH-DA). MCF-7 cells were seeded in a 96-well plate, treated with capsicodendrin, daunomycin, vitamin $\mathrm{C}$ or DMSO and followed by $5 \mathrm{~h}$ incubation at $37^{\circ} \mathrm{C}$ with $5 \% \mathrm{CO}_{2}$. Subsequently, cells were incubated with $\mathrm{H}_{2} \mathrm{O}_{2}(1.25 \mathrm{mM})$ and FeSO 4 for $30 \mathrm{~min}$ at $37^{\circ} \mathrm{C}$. Later, the fluorescent probe DCFH-DA was added to determine intracellular ROS. Fluorescence was measured using FLUOstar Optima fluorescence plate reader (BMG Lab technologies $\mathrm{GmbH}$ Inc.) at an excitation wavelength of $485 \mathrm{~nm}$ and emission wavelength of $530 \mathrm{~nm}$. All treatments performed in triplicate are representative of at least two different experiments.

Cell cycle. Cells were plated and treated using five different concentrations of capsicodendrin. After $12 \mathrm{~h}$ of incubation, cells were harvested and pelleted by centrifugation, washed with PBS and fixed in ice-cold $70 \%$ ethanol. The DNA was stained with $10 \mu \mathrm{g} / \mathrm{ml}$ propidium iodine (PI) in a reaction solution containing $1 \mathrm{mM}$ EDTA and $100 \mu \mathrm{g} / \mathrm{ml}$ RNase A. Fluorescence emitted from the propidium iodine-DNA complex was quantified using BD FACS Canto II (Biosciences, San Jose, CA, USA) at $488 \mathrm{~nm}$.

Mitochondrial transmembrane potential $\left(\Delta \Psi_{m}\right)$ assay. The mitochondrial transmembrane potential (MTP) fluorescence-activated cell sorting (FACS) assay kit (Cayman Chemical Company, Ann Arbor, MI, USA) was used to assess MTP $(\Delta \Psi \mathrm{m})$ in MCF-7 cells after treatment, using FACS analysis (12). Cells were seeded on $10 \mathrm{~cm}$ plates and treated with capsicodendrin for $24 \mathrm{~h}$. Next, cells were harvested using Trypsin-EDTA (Gibco), washed in phosphate-buffered saline (PBS) and re-suspended in assay buffer. The potentiometric dye 5,5',6,6'-tetrachloro-1,1',3,3'-tetraethylbensimidazoylcarbocyanine iodide (JC-1) was used to stain MCF-7 cells. A volume of $50 \mu \mathrm{l}$ of JC1 stain was added to the cells and incubated for $15 \mathrm{~min}$ at $37^{\circ} \mathrm{C}$ in $5 \%$ $\mathrm{CO}_{2}$. At high $\Psi \Delta \mathrm{m}$, red fluorescence J-aggregates are formed in healthy cells; however, in apoptotic cells with low $\Delta \Psi \mathrm{m}$, JC-1 remains in the monomeric form, which only exhibits green fluorescence. Analysis was performed using FACS Canto II (BD Bioscience, San Jose, CA, USA). The mitochondrial function was assessed, and the Jaggregates were detected using an excitation wavelength of 520-570 $\mathrm{nm}$, and emission of $570-610 \mathrm{~nm}$, respectively.

Caspase-Glo 1 inflammasome assay. Caspase-1 activity was determined using a modified protocol from Promega Caspase-Glo ${ }^{\circledR}$ 1 Inflammasome Assay (G9951) (Promega, Madison, WI, USA). MCF-7 cells were plated overnight in white 96-well plates in $100 \mu \mathrm{l}$ medium at a density of $20 \times 10^{4} \mathrm{cells} / \mathrm{ml}$, and at $37^{\circ} \mathrm{C}$ in a humidified $5 \% \mathrm{CO}_{2}$ incubator. Next, cells were treated with capsicodendrin or doxorubicin (control), for $24 \mathrm{~h}$. Four concentrations of both capsicodendrin and the control were tested, using the $\mathrm{IC}_{50}$ value as the second concentration and one concentration $5 \times$ higher than $\mathrm{IC}_{50}$ as well as two concentrations $5 \times$ and $10 \times$ lower than the $\mathrm{IC}_{50}$ value. Reagents used in the assay were prepared according to the specifications detailed by the manufacturer. After treatment, $70 \mu \mathrm{l}$ of medium was then discarded and the appropriate volume of CaspaseGlo ${ }^{\circledR} 1$ Reagent was added, while Caspase-Glo ${ }^{\circledR} 1$ YVAD-CHO Reagent was added at a ratio of 1:1 sample volume to reagent volume. The plate was then incubated at room temperature for $1 \mathrm{~h}$ and the luminescence was measured up to 120 min using a Fluostar Optima plate reader (BMG Labtech Inc.).

\section{Results and Discussion}

Capsicodendrin was isolated from the bark of Cinnamosma fragrans Baill. (Canellaceae) (Figure 1A) (14). C. fragrans is a medicinal plant endemic to Madagascar and is used in the treatment of malaria symptoms, fatigue, intestinal parasite infections, intoxication and headaches $(14,15)$.

The results obtained from the SRB assay showed that capsicodendrin displayed cytotoxic activity in the MCF-7 hormone-dependent breast cancer cell line $\left(\mathrm{IC}_{50}=7.5 \mu \mathrm{M}\right)$, suggesting the potential for further analysis as breast cancer is a leading cause of death in women. The cytotoxic activity was compared to the inhibitory activity of paclitaxel $\left(\mathrm{IC}_{50}=0.0021 \mu \mathrm{M}\right)$. Capsicodendrin has previously displayed cytotoxic activity against other cancer cell lines: HeLa 
A

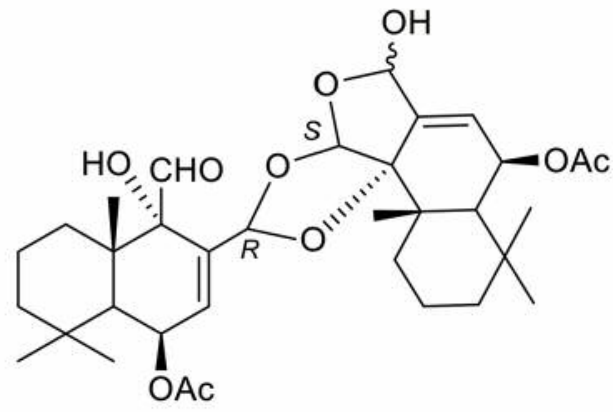

B

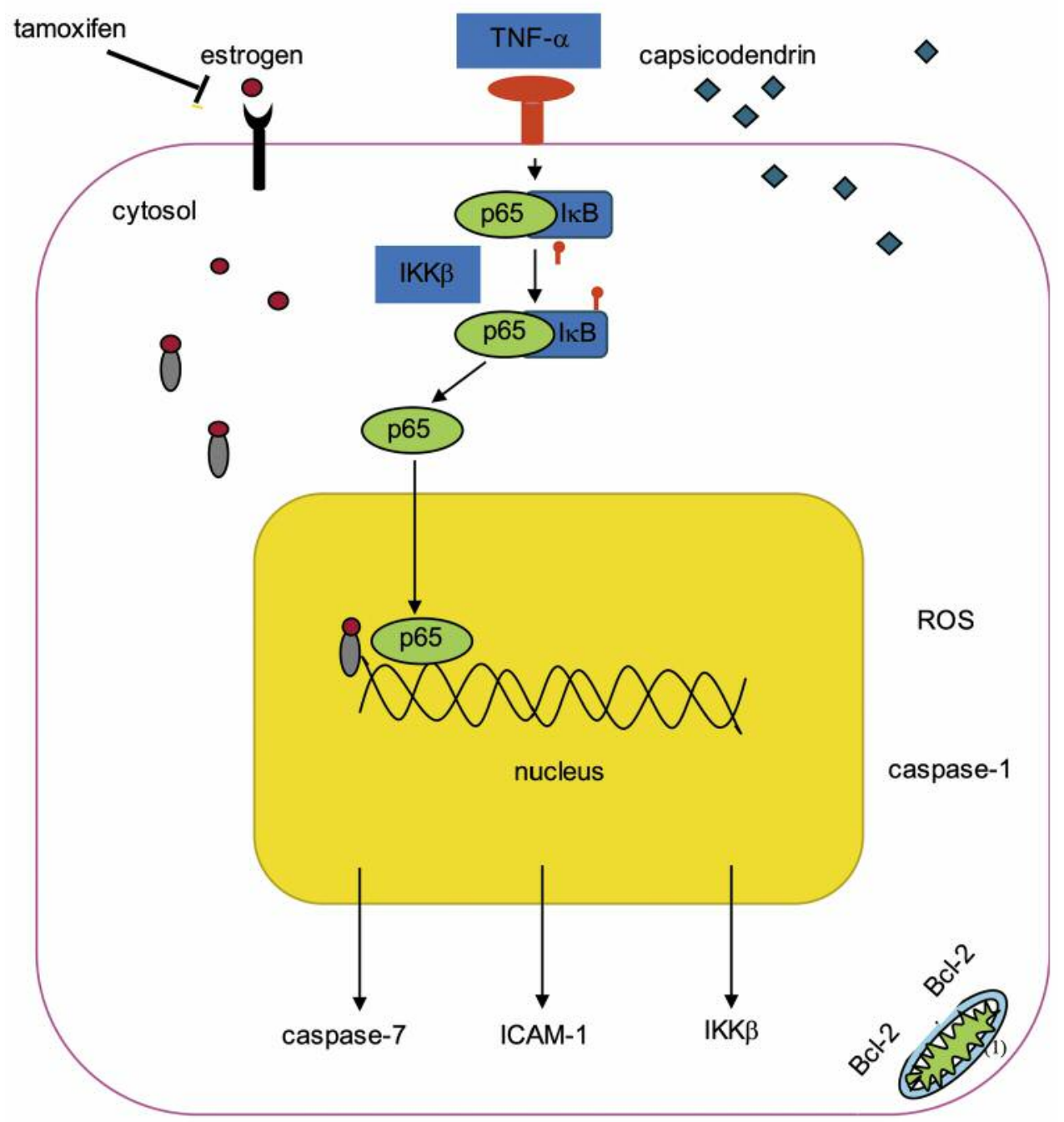

Figure 1. Capsicodendrin role in the NF-KB p65 pathway. (A) Structure of capsicodendrin isolated from Cinnamosma fragrans and (B) proposed pathway for the transcription factor $N F-k B$ p65 in MCF-7 estrogen-dependent cells.

cervical cells $\left(\mathrm{IC}_{50}=2.97 \mu \mathrm{M}\right)$, HT-29 colon cancer cells $\left(\mathrm{IC}_{50}=1.04 \mu \mathrm{M}\right)$ and murine leukemia cell line $\mathrm{L} 1210 / 0$ $\left(\mathrm{IC}_{50}=0.58 \mu \mathrm{M}\right)$, human T-lymphocyte cell lines Molt $4 / \mathrm{C} 8$ $\left(\mathrm{IC}_{50}=1.51 \mu \mathrm{M}\right)$ and $\mathrm{CEM} / 0\left(\mathrm{IC}_{50}=1.61 \mu \mathrm{M}\right)(14,16,17)$.
Capsicodendrin also displayed NF-kB inhibitory activity $\left(\mathrm{IC}_{50}=8.6 \mu \mathrm{M}\right)$ when tested by using the NF-kB p65 ELISA assay (Figure 1B). The NF-kB p65 inhibitory effect in HeLa cells was compared to that of rocaglamide $\left(\mathrm{IC}_{50}=0.075 \mu \mathrm{M}\right)$. 


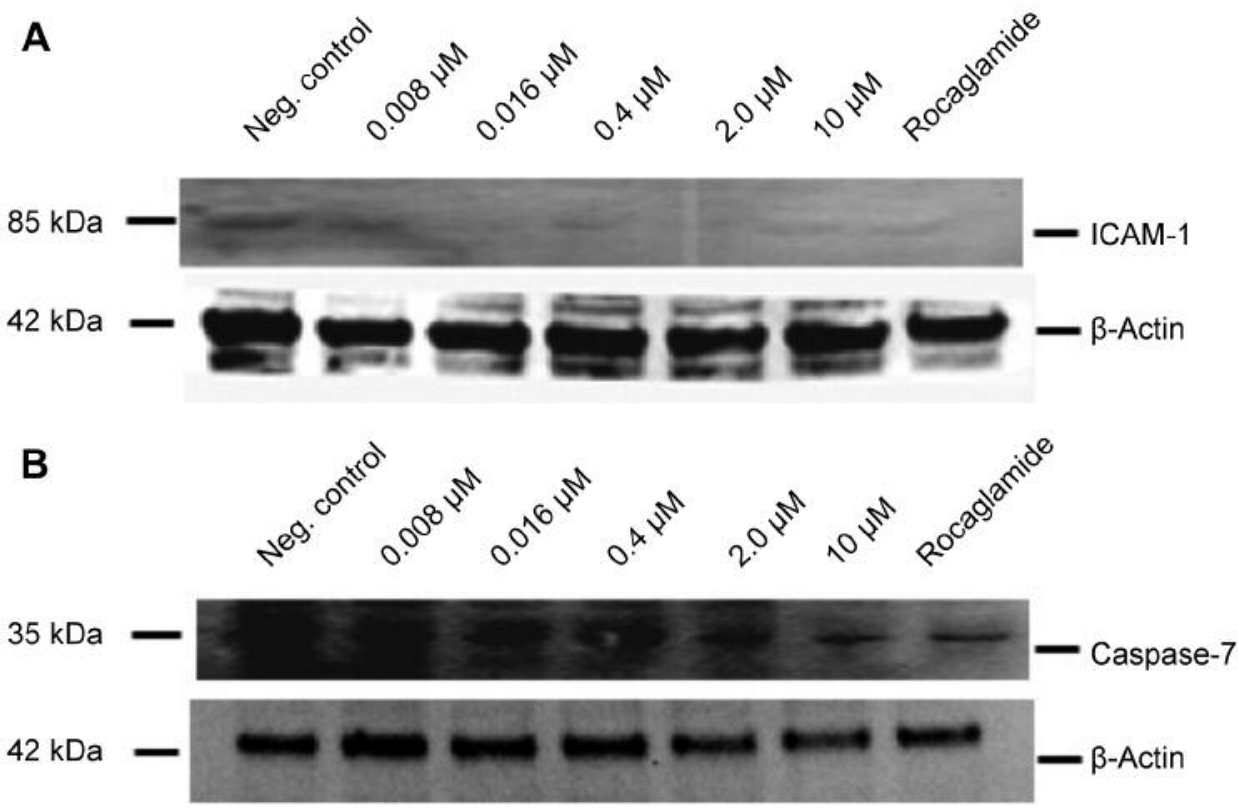

Figure 2. Immunoblotting studies on $N F-k B$. (A) Western blot analysis shows the expression of the transcription factor $N F-k B$ after $3 h$ of incubation with capsicodendrin. The NF-kB subunit p65 (Rel A) was down-regulated in capsicodendrin-treated MCF-7 cells and the effect on protein expression was concentration-dependent. The positive control was treated with rocaglamide and the negative control was not treated. $\beta$-Actin was used as an internal control. (B) Western blot analysis showed the expression of proteins in the $N F-k B$ pathway. The expression of IkB kinase $\beta$ (IKK $\beta$ ) was down-regulated in capsicodendrin-treated MCF-7 cells in a concentration-dependent manner. $\beta$-Actin was used as an internal control.

Subsequently, western blot analysis was performed at five different concentrations to assess the expression levels of NF-kB p65 in hormone-dependent breast cancer MCF-7 cells. At the concentration of $0.04 \mu \mathrm{M}$, the levels of NF-KB p65 were down-regulated in capsicodendrin-treated MCF-7 cells when compared to untreated cells (Figure 2A).

Furthermore, IKK is a pivotal upstream regulator of the NF$\mathrm{kB}$ pathway (18). Thus, the effect on the upstream IKK $\beta$ was assessed (Figure 2B). Capsicodendrin decreased the expression of IKK $\beta$ as shown by western blot analysis at the treated concentration of $0.04 \mu \mathrm{M}$. It has previously been shown that NF-kB acts as a pro-metastatic factor, facilitating adhesion of tumor cells to endothelial cells and has also been reported that capsicodendrin prevented the formation of new blood vessels (19). In the present study, it was shown that the expression of intracellular adhesion molecule (ICAM-1) was down-regulated in MCF-7 cells that were treated with capsicodendrin at 0.016 $\mu \mathrm{M}$ (Figure 3A). The glucoprotein ICAM-1 is a member of the immunoglobulin superfamily. It is an essential molecule in cellto-cell adhesion and mediates interaction between different cells. Silencing the expression of ICAM -1 decreases colonyformation in MCF-7 tumor cells and reduces cell adhesion. Further, it is involved in the transmigration of tumor cells and during metastasis. The down-regulation of human ICAM-1 inhibits the invasion and metastatic ability of human breast cancer cell lines (20). A previous study has also shown that
NF-kB p65 inhibition suppressed expression of ICAM-1 and sensitized cells to anticancer compound treatment $(21,22)$. Additionally, the present findings are in complete agreement with our previous studies performed in order to understand the mechanism of action of capsicodendrin, and demonstrated that it displayed angiostatic activity through selective inhibition of VEGFR2-mediated AKT signaling and dysregulated autophagy in endothelial cells during angiogenesis (21). In addition, it has previously been shown that ICAM-1 is under the control of NF-kB in MCF-7 cells during the metastatic phase when tumor cells migrate through the vessels in the lymphatic route (22). Thus, ICAM-1 is a key player in cancer and the effect of capsicodendrin on this target is worthy of further study.

Moreover, treatment with capsicodendrin induced oxidative stress in treated estrogen-sensitive MCF-7 cells. The levels of ROS increased in capsicodendrin-treated cells compared to cells treated with the positive control daunomycin (Figure 4). Similarly, it has been found that capsicodendrin depleted glutathione in human myeloid leukemia cells and reduced the intracellular antioxidant capacity of cancer cells (23). This suggests that oxidative stress promoted cell death in treated MCF-7 cells. Studies have shown that ROS play an important role in multidrug resistance in MCF-7 cells and thus together with the inhibition of NF-kB p65, the mechanism of action of capsicodendrin may prevent chemoresistance in cancer patients (24). 


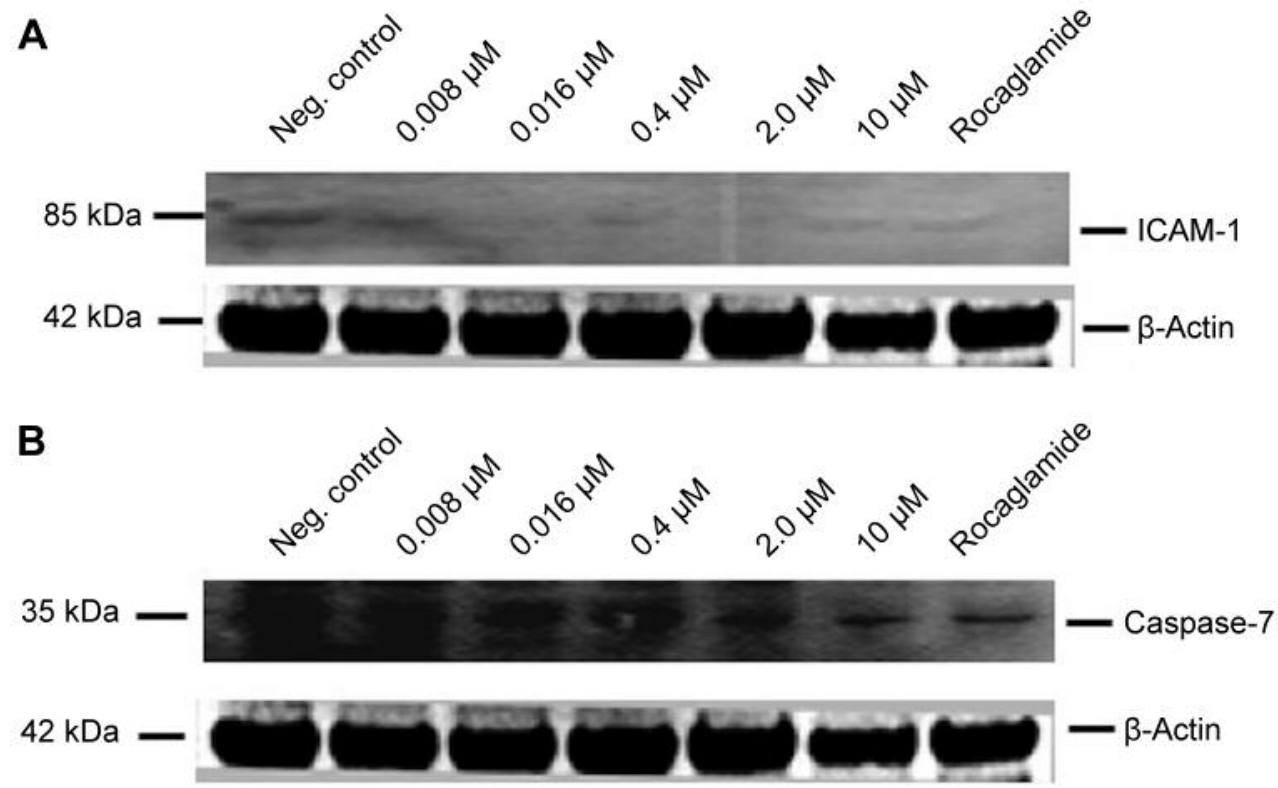

Figure 3. Expression of ICAM-1 and caspase-7. (A) ICAM-1 expression in capsicodendrin-treated MCF-7 cells after 3 h of treatment. Decreased levels of adhesion molecule ICAM-1 were detected in TNF- $\alpha$ treated cells. The effect was concentration-dependent. (B) The effect of capsicodendrin on caspase-7 expression after $3 \mathrm{~h}$ of treatment in MCF-7 cells breast cancer cells was analyzed. Immunoblot analysis showed that increasing concentrations of caspsicodendrin led to decreased levels of caspase-7. The effect was concentration-dependent. The effect was compared with rocaglamide, the positive control.

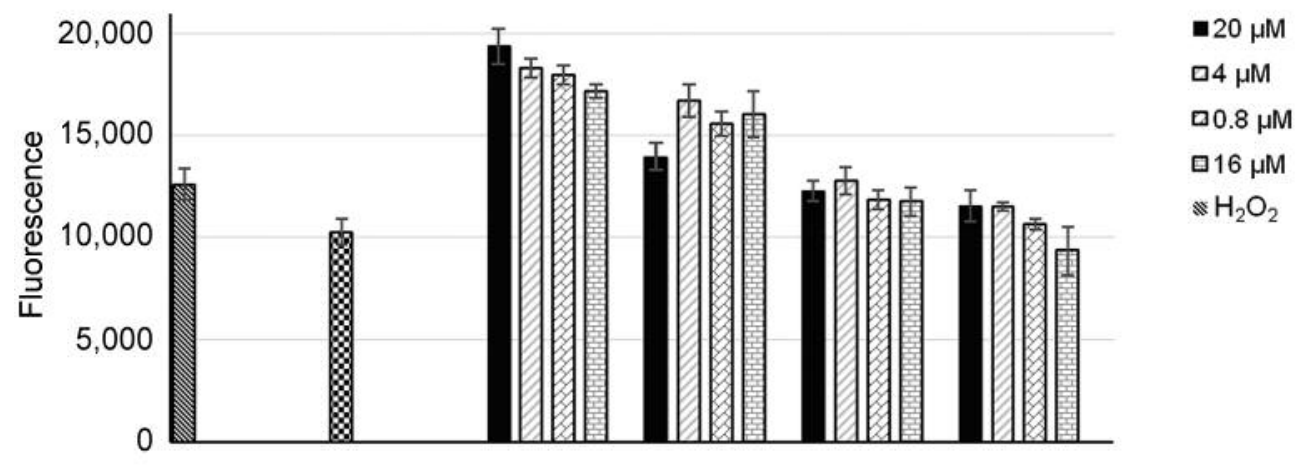

$\mathrm{H}_{2} \mathrm{O}_{2}$ Vitamin $\mathrm{C}+\mathrm{H}_{2} \mathrm{O}_{2} \quad \mathrm{CPCD}$ Daunomycin $\mathrm{CPCD}+\mathrm{H}_{2} \mathrm{O}_{2}$ Daunomycin $+\mathrm{H}_{2} \mathrm{O}_{2}$

Figure 4. Intracellular levels of reactive oxygen species (ROS) formed in capsicodendrin treated estrogen-dependent breast cancer MCF-7 cells after $5 \mathrm{~h}$ of treatment. The effect was compared to the positive control daunomycin (a topoisomerase inhibitor). The cells were treated at four different concentrations. The formation of ROS was detected with the fluorescent probe DCFH-DA. The highest concentration of capsicodendrin $(20 \mu M)$ led to a higher ROS formation than the highest concentration of daunomycin $(20 \mu M)$. The effect of capsicodendrin was concentrationdependent. Vitamin $C$ was used as a negative control.

The effect of capsicodendrin on cell-cycle arrest was examined using FACS. The sub $\mathrm{G}_{1}$-phase population increased to $81 \%$ after $12 \mathrm{~h}$ of treatment with capsicodendrin $(10 \mu \mathrm{M})$. This was compared to $46 \%$ of cells detected in sub $\mathrm{G}_{1}$-phase in non-treated MCF-7 cells (Figure 5A-F). There was a significant loss of cells and the results showed that cell cycle arrest had been induced. The effect observed was concentration-dependent; however, mitochondrial induced cell-death was not observed in capsicodendrin-treated cells and JC-1 monomers were not detected (Figure 6). The results showed no loss of the outer $\Delta \Psi \mathrm{m}$ nor mitochondrial dysfunction or cell-death in capsicodendrin-treated MCF-7 

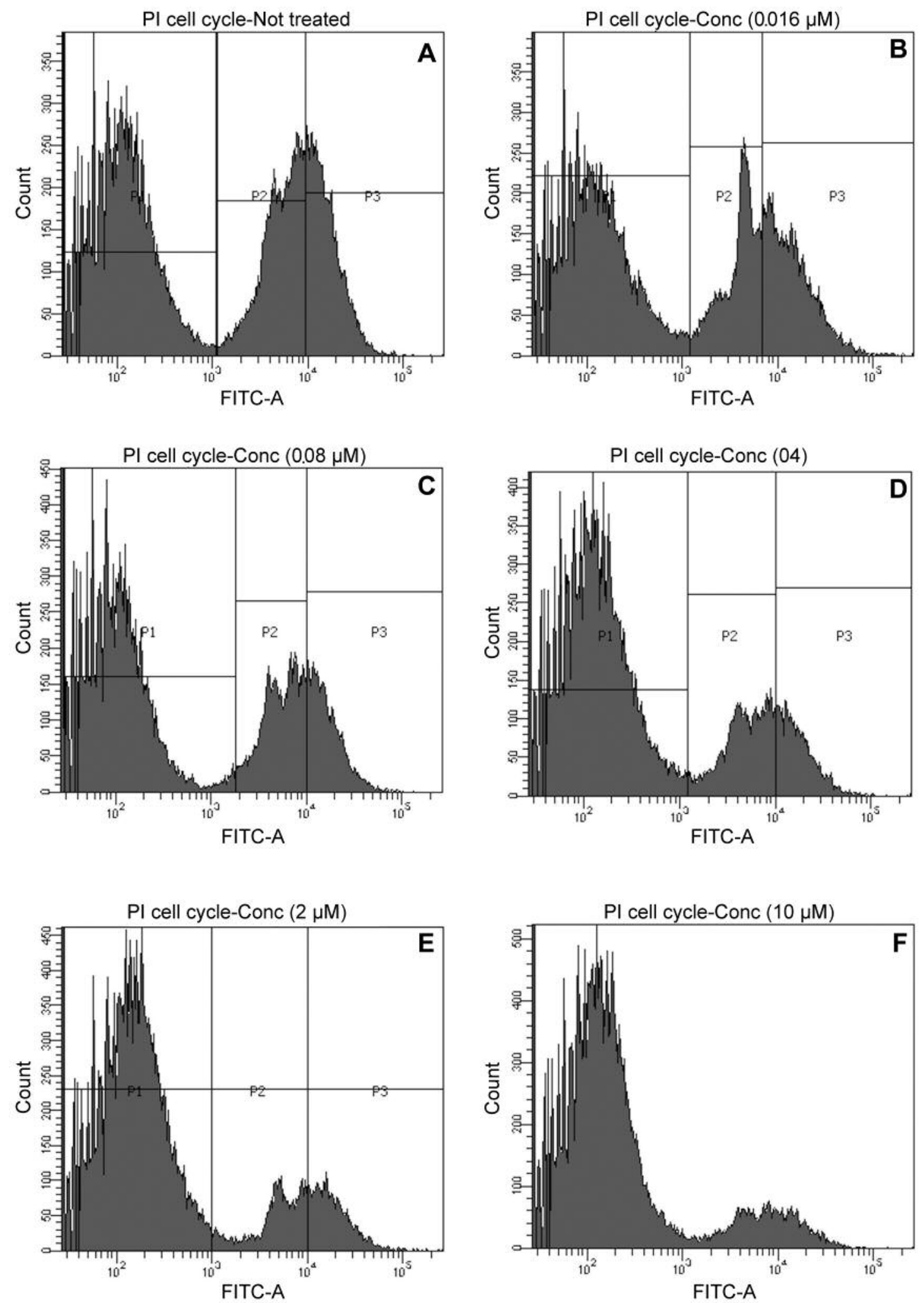

Figure 5. The effect of capsicodendrin on DNA fragmentation was evaluated in MCF-7 cells using fluorescence-activating cell flow cytometry (FACS). The cells were treated with capsicodendrin at five different concentration levels for $12 \mathrm{~h}:(A)$ control, $(B) 0.0016 \mu M,(C) 0.008 \mu M,(D)$ $0.4 \mu \mathrm{M},(E) 2.0 \mu \mathrm{M},(F) 10 \mu \mathrm{M}$. The increasing concentration of capsicodendrin led to an increase in the number of cells in sub-G $\mathrm{G}_{1}$ phase. 

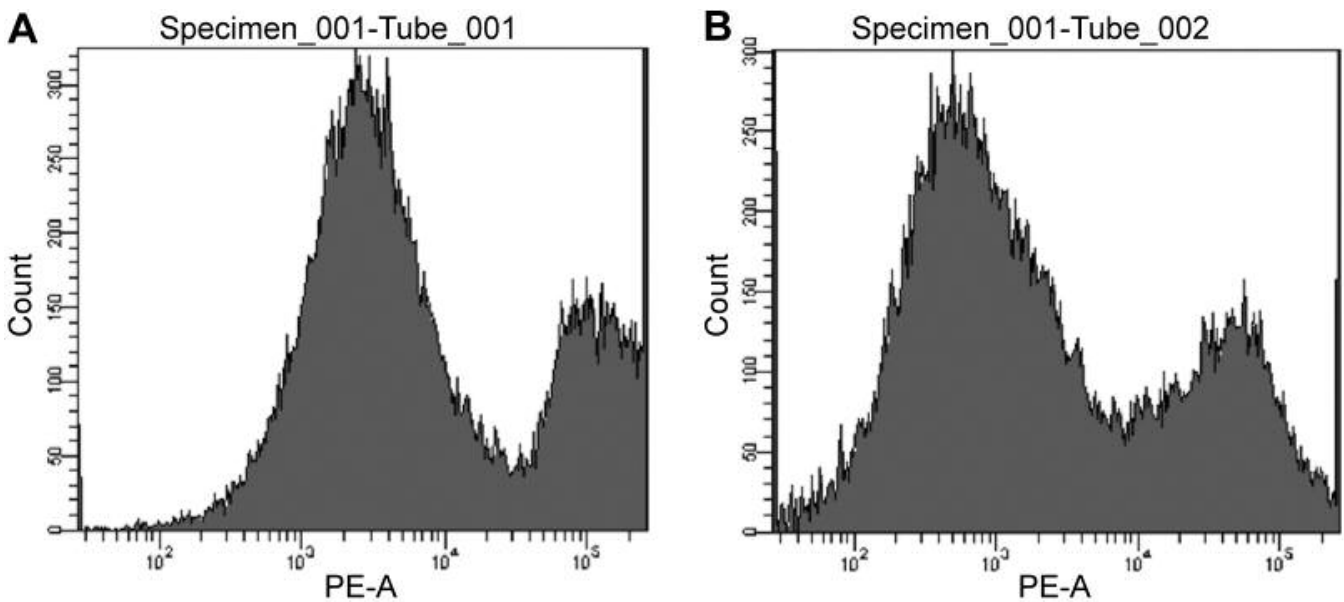

Figure 6. The loss of mitochondrial membrane potential $(\Delta \Psi m)$ is a major event during apoptosis. $\Delta \Psi m$ was assessed using the cationic dye JC-1 in MCF-7 cells treated without (A) or with capsicodendrin (B). In apoptotic unhealthy cells, JC-1 monomers were detected, as indicated by the green fluorescent cells when analyzed by cell flow cytometry. There was no increase in the formation of JC-1 monomers (564-606 nm) in capsicodendrin-treated cells when compared with untreated cells.

cells. Hence, the effect was found to be independent of mitochondrial activity.

According to previous studies, MCF-7 cells have a high expression of the anti-apoptotic protein Bcl-2 and lack the cellular response to apoptotic stimuli such as $e . g$., the activity of caspase- $3(25,26)$. To further understand the mechanism and the biochemical interactions through which capsicodendrin promoted cell-cycle arrest in MCF-7 cells, the effect on both caspase- 1 and caspase -7 were investigated.

Caspase- 1 is part of the inflammasome and is involved in inflammatory response. It has been shown to activate proinflammatory cytokine IL-1 $\beta$ (27). Increasing evidence suggests that IL-1 $\beta$ might be involved in autoinflammatory diseases of unknown origin (28). Recent studies have shown that there are increased levels of IL- $1 \beta$ in the tumor microenvironment of breast cancer tissue. An increase in IL-1 $\beta$ was estrogendependent and IL-antagonists inhibited tumor development and angiogenesis (29-31). Herein, we report the effect of capsicodendrin on caspase-1 enzymatic activity in MCF-7 cells (Figure 7A). Capsicodendrin $(0.12-3.50 \mu \mathrm{M})$ increased caspase1 activity in a caspase-1 GLO assay compared with doxorubicin (0.14-3.5 $\mu \mathrm{M}$ ) (Figure 7B). In addition, treatment with increasing concentrations of caspsicodendrin $(0.12-3.0 \mu \mathrm{M})$ induced caspase- 1 activity even in cells treated with the inhibitor YVAD-CHO. The effect correlates with increased levels of ROS and suggests that ROS promotes the activity of caspase-1. This effect was both concentration-dependent and time-dependent. It has previously been reported that caspase- 1 induces p53-dependent cell-cycle arrest and inflammasomemediated apoptosis in estrogen dependent MCF-7 cells (32).

Earlier studies have shown that the levels of caspase- 7 are over-expressed in estrogen-dependent breast cancer cells and thus the levels were evaluated in capsicodendrin wild-type p53 protein expressing MCF-7 cells $(33,34)$. The results of this study showed that the levels of caspase-7 were downregulated in capsicodendrin-treated (0.008-10 $\mu \mathrm{M}) \mathrm{MCF}-7$ cells (Figure 3B). The CASP7 promoter has five estrogen responsive elements and thus could represent potential specific targets in estrogen-dependent cancer cells (33). Furthermore, caspase-7 targets various cell-cycle inhibitors such as p21 and DNA repair proteins $(35,36)$. It has been shown that reduction in p21 contributes to proliferation and cell growth. Cyclindependent kinases (CDKs) play an important role and promote cell cycle progression (37). Thus, CDK inhibitory proteins, such as p21, inhibit CDK activity, which, in turn, causes cellcycle arrest in $G_{1} / S$ phase and negatively affects cancer cell proliferation $(38,39)$. The down-regulated levels of caspase7 correlated with the cell cycle arrest in MCF-7 treated cells. This inhibitory effect may have depended on the inhibitory effect of p21 on cell proliferation (33).

Furthermore, in our previous studies, capsicodendrin was shown to be able to be converted to its more reactive monomer cinnamodial, in the presence of nucleophilic solvents such as pyridine and DMSO in vitro. We proposed that capsicodendrin is present in plants as a chemical reservoir of the bioactive cinnamodial against predators (20). The conversion of capsicodendrin to cinnamodial may qualify the compound as a prodrug; however, this remains to be evaluated in vivo. In this study, we focused on understanding the antiproliferative mechanisms of capsicodendrin against MCF-7 cells. Diligent efforts were made to use as little DMSO as possible during the assays in order to specifically examine the effect of capsicodendrin. In summary, the results from this study showed that capsicodendrin inhibited the NF-kB pathway, increased 

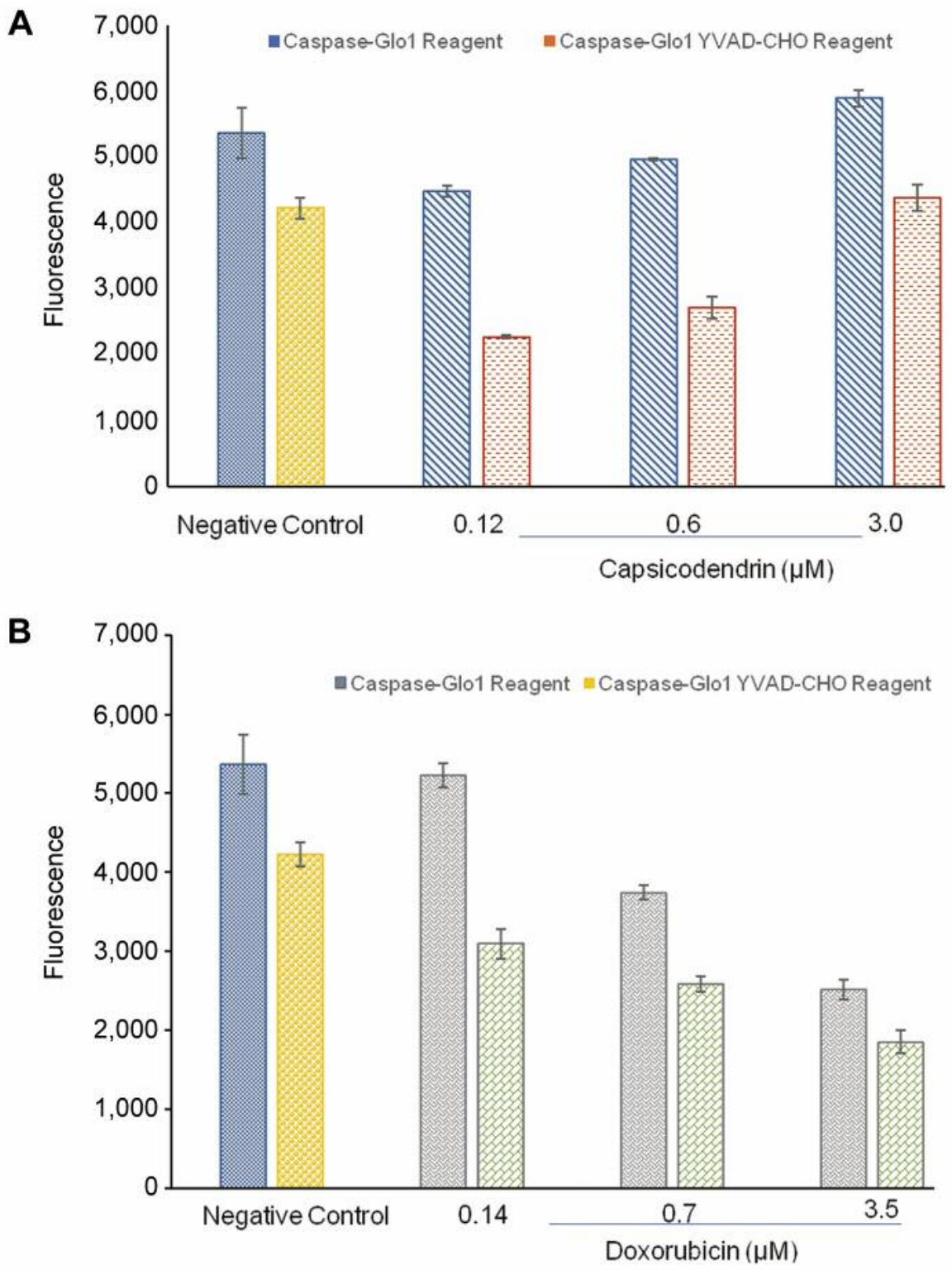

Figure 7. Caspase-1 activity was determined using a modified protocol from Promega Caspase-Glo ${ }^{\circledR} 1$ Inflammasome Assay (G9951). The YVADCHO is a specific caspase-1 inhibitor. The MCF-7 cells were treated with doxorubicin (topoisomerase inhibitor) and capsicodendrin. Capsicodendrin $(0.12-3.50 \mu M)(A)$ increased caspase-1 activity compared with doxorubicin (0.14-3.5 $\mu M)$ that showed inhibitory activity (B). Increased concentration levels of caspsicodendrin $(0.12-3.0 \mu \mathrm{M})$ induced caspase-1 activity. Capsicodendrin potentiated caspase-1 activity in a concentrationdependent manner. The effect was compared to the negative control.

oxidative stress, induced cell-death through caspase-1, and down-regulated the expression of caspase-7. Targeting the NF$\mathrm{kB}$ pathway could potentiate the effect of existing anticancer treatments in the management of metastatic cancer $(33,40,41)$.

\section{Conclusion}

The findings from the present drug discovery study showed that the NF-kB inhibitory effect of capsicodendrin induced cell death through a mitochondrial-independent pathway in malignant MCF-7 cells. The NF-kB inhibitory effect of capsicodendrin increased oxidative stress, the activity of caspase-1, and decreased the expression of estrogen-dependent caspase-7. In conclusion, inhibitors that target the NF-kB p65 signal pathway may induce additive anti-cancer therapeutic effects. Capsicodendrin and its potential analogues may be novel anticancer agents targeting metastatic breast cancer cells that may improve the prognosis of recurrent breast cancers. 


\section{Conflicts of Interest}

The Authors declare no conflicts of interest in relation to this study.

\section{Authors' Contributions}

Dr. Esperanza J. Carcache de Blanco coordinated and supervised overall efforts and conceived experiments in vitro as well as participated in the preparation and revision of the manuscript. Dr. L. Harinantenaina Rakotondraibe provided capsicodendrin as he isolated and identified it in his laboratory. Mr. Nathan Ezzone performed experiments in the ROS assay and the Caspase-Glo assay. Dr. Ulyana Munoz Acuna performed the NF-kB p65 assay, FACS study, the JC-1 assay western blot analysis, analyzed the data and participated in the preparation of the manuscript.

\section{Acknowledgements}

The Authors greatly acknowledge the financial support through program project grant P01 CA125066 and its supplement P01 CA125066-10S1 from the National Cancer Institute, NIH, Bethesda, MD to carry out the presented work. The Authors are also thankful for the partial support provided by the Jack L. Beal Endowment Fund of Dr. A. Douglas Kinghorn for Mr. Nathan Ezzone.

\section{References}

1 Siegel RL, Miller KD and Jemal A: Cancer statistics, 2017. CA Cancer J Clin 67(1): 7-30, 2017. PMID: 28055103. DOI: $10.3322 /$ caac. 21387

2 Cardoso F, Costa A, Norton L, Cameron D, Cufer T, Fallowfield L, Francis P, Gligorov J, Kyriakides S, Lin N, Pagani O, Senkus E, Thomssen C, Aapro M, Bergh J, Di Leo A, El Saghir N, Ganz PA, Gelmon K, Goldhirsch A, Harbeck N, Houssami N, Hudis C, Kaufman B, Leadbeater M, Mayer M, Rodger A, Rugo H, Sacchini V, Sledge G, van't Veer L, Viale G, Krop I and Winer E: 1st International consensus guidelines for advanced breast cancer (ABC 1). Breast 21(3): 242-252, 2012. PMID: 22425534. DOI: $10.1016 /$ j.breast.2012.03.003

3 Chitapanarux I, Sripan P, Somwangprasert A, Charoentum C, Onchan W, Watcharachan K, Wongmaneerung P, Kongmebhol P, Jia-Mahasap B and Huntrakul L: Stage-specific survival rate of breast cancer patients in northern Thailand in accordance with two different staging systems. Asian Pac J Cancer Prev 20(9): 26992706, 2019. PMID: 31554366. DOI: 10.31557/APJCP.2019. 20.9.2699

4 Zhang Z, Lin G, Yan Y, Li X, Hu Y, Wang J, Yin B, Wu Y, Li Z and Yang XP: Transmembrane TNF-alpha promotes chemoresistance in breast cancer cells. Oncogene 37(25): 3456-3470, 2018. PMID: 29559745. DOI: $10.1038 / \mathrm{s} 41388-018-0221-4$

5 Berberoglu U, Yildirim E and Celen O: Serum levels of tumor necrosis factor alpha correlate with response to neoadjuvant chemotherapy in locally advanced breast cancer. Int J Biol Markers 19(2): 130-134, 2004. PMID: 15255545. DOI: $10.1177 / 172460080401900207$

6 Oida K, Matsuda A, Jung K, Xia Y, Jang H, Amagai Y, Ahn G, Nishikawa S, Ishizaka S, Jensen-Jarolim E, Matsuda $H$ and Tanaka A: Nuclear factor-kB plays a critical role in both intrinsic and acquired resistance against endocrine therapy in human breast cancer cells. Sci Rep 4: 4057, 2014. PMID: 24531845. DOI: $10.1038 /$ srep04057

7 Liang P, Zhang H, Wang G, Li S, Cong S, Luo Y and Zhang B: KPNB1, XPO7 and IPO8 mediate the translocation of NF$\mathrm{kB} / \mathrm{p} 65$ into the nucleus. Traffic 14(11): 1132-1143, 2013. PMID: 23906023. DOI: 10.1111/tra.12097

8 Kashyap T, Argueta C, Aboukameel A, Unger TJ, Klebanov B, Mohammad RM, Muqbil I, Azmi AS, Drolen C, Senapedis W, Lee M, Kauffman M, Shacham S and Landesman Y: Selinexor, a Selective Inhibitor of Nuclear Export (SINE) compound, acts through NF-kB deactivation and combines with proteasome inhibitors to synergistically induce tumor cell death. Oncotarget 7(48): 78883-78895, 2016. PMID: 27713151. DOI: 10.18632/ oncotarget.12428

9 Darnell JE Jr: Transcription factors as targets for cancer therapy. Nat Rev Cancer 2(10): 740-749, 2002. PMID: 12360277. DOI: $10.1038 / \mathrm{nrc} 906$

10 Acuña UM, Shen Q, Ren Y, Lantvit DD, Wittwer JA, Kinghorn AD, Swanson SM and de Blanco EJ: Goyazensolide induces apoptosis in cancer cells in vitro and in vivo. Int J Cancer Res 9(2): 36-53, 2013. PMID: 25621077. DOI: 10.3923/ijcr. 2013.36.53

11 Yin $\mathrm{Y}$, Chen $\mathrm{X}$ and Shu Y: Gene expression of the invasive phenotype of TNF-alpha-treated MCF-7 cells. Biomed Pharmacother 63(6): 421-428, 2009. PMID: 19564093. DOI: 10.1016/j.biopha.2009.04.032

12 Kim H, Chung H, Kim HJ, Lee JY, Oh MY, Kim Y and Kong G: Id-1 regulates Bcl-2 and Bax expression through p53 and NFkappaB in MCF-7 breast cancer cells. Breast Cancer Res Treat 112(2): 287-296, 2008. PMID: 18158619. DOI: 10.1007/s 10549007-9871-6

13 Lerebours F, Vacher S, Andrieu C, Espie M, Marty M, Lidereau $\mathrm{R}$ and Bieche I: NF-kappa $\mathrm{B}$ genes have a major role in inflammatory breast cancer. BMC Cancer 8: 41, 2008. PMID: 18248671. DOI: $10.1186 / 1471-2407-8-41$

14 Figenschau SL, Knutsen E, Urbarova I, Fenton C, Elston B, Perander M, Mortensen ES and Fenton KA: ICAM1 expression is induced by proinflammatory cytokines and associated with TLS formation in aggressive breast cancer subtypes. Sci Rep 8(1): 11720, 2018. PMID: 30082828. DOI: 10.1038/s41598-01829604-2

15 Deng Y, Balunas MJ, Kim JA, Lantvit DD, Chin YW, Chai H, Sugiarso S, Kardono LB, Fong HH, Pezzuto JM, Swanson SM, de Blanco EJ and Kinghorn AD: Bioactive 5,6-dihydro-alphapyrone derivatives from Hyptis brevipes. J Nat Prod 72(6): 11651169, 2009. PMID: 19422206. DOI: 10.1021/np9001724

$16 \mathrm{Kim}$ JA, Lau EK, Pan L and De Blanco EJ: NF-kappaB inhibitors from Brucea javanica exhibiting intracellular effects on reactive oxygen species. Anticancer Res 30(9): 3295-3300, 2010. PMID: 20944100.

17 Harinantenaina L and Takaoka S: Cinnafragrins A-C, dimeric and trimeric drimane sesquiterpenoids from Cinnamosma fragrans, and structure revision of capsicodendrin. J Nat Prod 69(8): 1193-1197, 2006. PMID: 16933874. DOI: 10.1021/np0601298

18 Razafindraibe M, Kuhlman AR, Rabarison H, Rakotoarimanana V, Rajeriarison C, Rakotoarivelo N, Randrianarivony $\mathrm{T}$, Rakotoarivony F, Ludovic R, Randrianasolo A and Bussmann RW: Medicinal plants used by women from Agnalazaha littoral forest (Southeastern Madagascar). J Ethnobiol Ethnomed 9: 73, 2013. PMID: 24188563. DOI: 10.1186/1746-4269-9-73 
19 Perkins ND: Integrating cell-signalling pathways with NFkappaB and IKK function. Nat Rev Mol Cell Biol 8(1): 49-62, 2007. PMID: 17183360 . DOI: $10.1038 / \mathrm{nrm} 2083$

20 Pan CC, Shah N, Kumar S, Wheeler SE, Cinti J, Hoyt DG, Beattie CE, An M, Mythreye K, Rakotondraibe LH and Lee NY: Angiostatic actions of capsicodendrin through selective inhibition of VEGFR2-mediated AKT signaling and disregulated autophagy. Oncotarget 8(8): 12675-12685, 2017. PMID: 27177332. DOI: 10.18632/oncotarget.9307

21 Di D, Chen L, Wang L, Sun P, Liu Y, Xu Z and Ju J: Downregulation of human intercellular adhesion molecule-1 attenuates the metastatic ability in human breast cancer cell lines. Oncol Rep 35(3): 1541-1548, 2016. PMID: 26751847. DOI: $10.3892 /$ or.2016.4543

22 Harada M, Morimoto K, Kondo T, Hiramatsu R, Okina Y, Muko R, Matsuda I and Kataoka T: Quinacrine inhibits ICAM-1 transcription by blocking DNA binding of the NF-kB subunit p65 and sensitizes human lung adenocarcinoma A549 cells to TNF- $\alpha$ and the Fas ligand. Int J Mol Sci 18(12): 2603, 2017. PMID: 29207489. DOI: 10.3390/ijms 18122603

23 Viola K, Kopf S, Huttary N, Vonach C, Kretschy N, Teichmann M, Giessrigl B, Raab I, Stary S, Krieger S, Keller T, Bauer S, Hantusch B, Szekeres T, de Martin R, Jäger W, Mikulits W, Dolznig H, Krupitza $\mathrm{G}$ and Grusch M: Bay11-7082 inhibits the disintegration of the lymphendothelial barrier triggered by MCF-7 breast cancer spheroids; the role of ICAM-1 and adhesion. Br J Cancer 108(3): 564-569, 2013. PMID: 23093227. DOI: 10.1038/bjc.2012.485

24 Karmahapatra S, Kientz C, Shetty S, Yalowich JC and Rakotondraibe LH: Capsicodendrin from Cinnamosma fragrans exhibits antiproliferative and cytotoxic activity in human leukemia cells: Modulation by glutathione. J Nat Prod 81(3): 625-629, 2018. PMID: 29406734. DOI: 10.1021/acs.jnatprod. $7 \mathrm{~b} 00887$

25 Cen J, Zhang L, Liu F, Zhang F and Ji BS: Long-term alteration of reactive oxygen species led to multidrug resistance in MCF7 cells. Oxid Med Cell Longev 2016: 7053451, 2016. PMID: 28058088. DOI: $10.1155 / 2016 / 7053451$

26 Brinkmann U, Mansfield E and Pastan I: Effects of BCL-2 overexpression on the sensitivity of MCF-7 breast cancer cells to ricin, diphtheria and Pseudomonas toxin and immunotoxins. Apoptosis 2(2): 192-198, 1997. PMID: 14646554. DOI: 10.10 23/a: 1026468532413

27 Colombel M, Symmans F, Gil S, O'Toole KM, Chopin D, Benson M, Olsson CA, Korsmeyer S and Buttyan R: Detection of the apoptosis-suppressing oncoprotein bc1-2 in hormonerefractory human prostate cancers. Am J Pathol 143(2): 390-400, 1993. PMID: 7688182.

28 Rubis B, Holysz H, Gladych M, Toton E, Paszel A, Lisiak N, Kaczmarek M, Hofmann $\mathrm{J}$ and Rybczynska M: Telomerase downregulation induces proapoptotic genes expression and initializes breast cancer cells apoptosis followed by DNA fragmentation in a cell type dependent manner. Mol Biol Rep 40(8): 4995-5004, 2013. PMID: 23677713. DOI: 10.1007/s11033-013-2600-9

29 Colina M, Pizzirani C, Khodeir M, Falzoni S, Bruschi M, Trotta $\mathrm{F}$ and Di Virgilio F: Dysregulation of P2X7 receptorinflammasome axis in SAPHO syndrome: successful treatment with anakinra. Rheumatology (Oxford) 49(7): 1416-1418, 2010. PMID: 20299381. DOI: 10.1093/rheumatology/keq074

30 Bar D, Apte RN, Voronov E, Dinarello CA and Cohen S: A continuous delivery system of IL-1 receptor antagonist reduces angiogenesis and inhibits tumor development. FASEB J 18(1): 161-163, 2004. PMID: 14597552. DOI: 10.1096/fj.03-0483fje

31 Lindahl G, Saarinen N, Abrahamsson A and Dabrosin C: Tamoxifen, flaxseed, and the lignan enterolactone increase stromaand cancer cell-derived IL-1Ra and decrease tumor angiogenesis in estrogen-dependent breast cancer. Cancer Res 71(1): 51-60, 2011. PMID: 21097717. DOI: 10.1158/0008-5472.CAN-10-2289

32 Abrahamsson A, Morad V, Saarinen NM and Dabrosin C: Estradiol, tamoxifen, and flaxseed alter IL-1 $\beta$ and IL-1Ra levels in normal human breast tissue in vivo. J Clin Endocrinol Metab 97(11): E2044-E2054, 2012. PMID: 22930784. DOI: 10.1210/jc.2012-2288

33 Thalappilly S, Sadasivam S, Radha V and Swarup G: Involvement of caspase 1 and its activator Ipaf upstream of mitochondrial events in apoptosis. FEBS J 273(12): 2766-2778, 2006. PMID: 16817903. DOI: $10.1111 / \mathrm{j} .1742-4658.2006 .05293 . x$

34 Chaudhary S, Madhukrishna B, Adhya AK, Keshari S and Mishra SK: Overexpression of caspase 7 is ER $\alpha$ dependent to affect proliferation and cell growth in breast cancer cells by targeting p21(Cip). Oncogenesis 5: e219, 2016. PMID: 27089142. DOI: 10.1038/oncsis.2016.12

35 Neve RM, Chin K, Fridlyand J, Yeh J, Baehner FL, Fevr T, Clark L, Bayani N, Coppe JP, Tong F, Speed T, Spellman PT, DeVries S, Lapuk A, Wang NJ, Kuo WL, Stilwell JL, Pinkel D, Albertson DG, Waldman FM, McCormick F, Dickson RB, Johnson MD, Lippman M, Ethier S, Gazdar A and Gray JW: A collection of breast cancer cell lines for the study of functionally distinct cancer subtypes. Cancer Cell 10(6): 515-527, 2006. PMID: 17157791. DOI: 10.1016/j.ccr.2006.10.008

36 Suzuki A and Shiraki K: Tumor cell "dead or alive": caspase and survivin regulate cell death, cell cycle and cell survival. Histol Histopathol 16(2): 583-593, 2001. PMID: 11332714. DOI: $10.14670 / \mathrm{HH}-16.583$

37 Stroh C and Schulze-Osthoff K: Death by a thousand cuts: an ever increasing list of caspase substrates. Cell Death Differ 5(12): 9971000, 1998. PMID: 9894605. DOI: 10.1038/sj.cdd.4400451

38 Sweeney KJ, Swarbrick A, Sutherland RL and Musgrove EA: Lack of relationship between CDK activity and G1 cyclin expression in breast cancer cells. Oncogene 16(22): 2865-2878, 1998. PMID: 9671407. DOI: 10.1038/sj.onc.1201814

39 Dickson RB, Huff KK, Spencer EM and Lippman ME: Induction of epidermal growth factor-related polypeptides by 17 beta-estradiol in MCF-7 human breast cancer cells. Endocrinology 118(1): 138142, 1986. PMID: 3000728. DOI: 10.1210/endo-118-1-138

40 Yang C, Chen L, Li C, Lynch MC, Brisken C and Schmidt EV: Cyclin D1 enhances the response to estrogen and progesterone by regulating progesterone receptor expression. Mol Cell Biol 30(12): 3111-3125, 2010. PMID: 20404095. DOI: 10.1128/MCB.01398-09

41 Liao XH, Lu DL, Wang N, Liu LY, Wang Y, Li YQ, Yan TB, Sun $\mathrm{XG}$, Hu $\mathrm{P}$ and Zhang TC: Estrogen receptor $\alpha$ mediates proliferation of breast cancer MCF-7 cells via a p21/PCNA/E2F1dependent pathway. FEBS J 281(3): 927-942, 2014. PMID: 24283290. DOI: $10.1111 /$ febs.12658

Received October 8, 2021

Revised November 12, 2021

Accepted November 18, 2021 